УДК 339.13:658

DOI: https://doi.org/10.37320/2415-3583/14.4

Бояринова К.О. доктор економічних наук, доцентка, доцентка кафедри менеджменту, Начіональний технічний університет Украӥни «Київський політехнічний інститут імені Ігоря Сікорського» ORCID: https://orcid.org/0000-0001-5879-2213

Бичковська А.А. магістрант,

Національний технічний університет Украйни «Київський політехнічний інститут імені Ігоря Сікорського»

\title{
ПРОБЛЕМИ ТА ПЕРСПЕКТИВИ ВПРОВАДЖЕННЯ ЕКОЛОГІЧНИХ ІННОВАЦІЙ НА ПІДПРИЕМСТВАХ
}

Дослідження зумовлене необхідністю забезпечення сталого розвитку підприємств та присвячене аналізу наявного стану, проблем та перспектив упровадження екологічних інноваџій на підприємствах. На основі використання монографічного методу, абстрактно-логічного, логічних узагальнень, формалізації та конкретизації розкрито проблемність, тенденції та особливості впровадження екологічних інновацій на вітчизняних промислових підприємствах. Розглянуто сутність екоінновацій та об'єкти, які їм належать. Обтрунтовано поділ екоінновацій промислового підприємства на інновації у виробничій діяльності, у зміні складу продуктів; в управлінській сфері. Проаналізовано тендениії впровадження на підприємствах маловідходних, ресурсозберігаючих, технологічних прочесів. Досліджено обсяги капітальних інвестицій в екологізацію за видами економічної діяльності підприємств України. 3 метою розвитку прочесів екологізацї запропоновано забезпечити низку економічних умов: розвиток страхового ринку; субсидіювання використання нетрадиційних джерел енергї̈; створення кластерів екологічно орієнтованого виробництва; підвищення інвестиційної привабливості еколозації виробництв; створення фондів спеціального призначення; формування програми розвитку екоінновацій у промисловості.

Ключові слова: екологічні інновації, екоінновації, підприємство, технологї, екологічне виробництво.

Постановка проблеми. Розвиток виробництв в епоху становлення циркулярної економіки потребує впровадження екологічних інновацій, особливо на промислових підприємствах. Це зумовлено необхідністю забезпечення їхнього сталого розвитку, підвищення конкурентоспроможності та соціальної відповідальності щодо охорони навколишнього середовища. Проблемність упровадження екоінновацій різних напрямів, у тому числі і в контексті зміни технологій виробництва, застосування ощадливого підходу та перехід на використання вторинної сировини актуалізує дослідження управлінсько-економічних аспектів провадження такої діяльності.
Аналіз останніх досліджень та публікацій. Питання екологічності виробництв, розроблення та впровадження інновацій перебувають у полі дослідження вітчизняних та зарубіжних учених, таких як: K. Rennings, T. Zwick, Л. Горбач, О. Савчук, Н. Яворська, I. Скороход, Н. Ребрина, Н. Андрєєва, Е. Мартинюк. Однак глобалізаційні процеси екологізації, орієнтація суспільства та урядів розвинених країн на вирішення екологічних питань промисловостей актуалізує дослідження проблемних аспектів та перспектив упровадження екоінновацій на підприємствах.

Мета статті. Метою статті є аналіз наявного стану, проблем та перспектив упровадження екологічних 
інновацій на підприємствах в умовах екологізації економічного розвитку.

Виклад основного матеріалу дослідження. Незважаючи на наростаючу світову проблему екологічності промисловості, необхідність підвищення екологічної стійкості підприємств, екоінновації все ще залишаються не досить опрацьованою площиною в економічному розвитку. Разові акції в системі екологічної політики підприємств не приводять до бажаних результатів. Саме тому впровадження продуктових та технологічних екологічних або базованих на їх основі інновацій потребує системності та відповідних інноваційних процесів.

Екоінноваціями науковцями та практиками вважаються і технологічні процеси, і змінена продукція, і використання нових екологічних ресурсів. Зокрема, такі інновації ними визначаються як: процеси, обладнання, продукція, методи і системи управління [1], зміни в технології, організаційній структурі і управлінні підприємством [2], прогресивні техніко-технологічні зміни у виробництві, які зумовлюють перехід на нові екологічні технології [3], виробництво, асиміляція або експлуатація продукту, процесу виробництва, обслуговування, управління або бізнес-методу [4]. Метою ж екологічно орієнтованої інноваційної діяльності підприємств вважається впровадження екологічно чистих безвідходних та маловідходних технологій, встановлення очисних споруд, виробництво екологічно чистої продукції [5]. Підтримуємо думку, що вчені розгалужено визначають сутність екоінновацій та їхній склад: екологічна інновація - це процес комерціалізації ідей та винаходів в екологічній сфері або це товар, технологія чи результат розробки екологічного характеру [6]. Загалом екоінновації поділяють на технологічні та нетехнологічні. Перші спрямовані на покращення техніко-технологічного забезпечення промислових підприємств. Другі - передбачають організаційні та інституційні зміни, зумовлені нормуючими заходами, економічними та екологічними впливами. Екоінновації мають місце не тільки у технологічних процесах, але й в управлінні підприємством та бізнесом. Вони передбачають запровадження нових продуктів чи послуг і зорієнтовані на значне поліпшення охорони навколишнього середовища.

Екологічні інновації варто поділяти за напрямами діяльності промислового підприємства. Насамперед це інновації у виробничій діяльності підприємства. До таких варто віднести інновації, завдяки яким зменшується кількість викидів у навколишнє середовище. Наступна група має стосуватися інновацій щодо зміни складу продуктів, а саме створення продукції з екологічно чистих матеріалів або вторинної сировини. В управлінській сфері до таких інновацій можна відносити управління відходами, запровадження нових методів енергоощадливості тощо.

Обравши європейський шлях розвитку, Україна має дотримуватися принципів та політики європейських країн щодо екологізації промислових підприємств. Зокрема єдина екологічна політика Євросоюзу базується на таких принципах, як [7]:

- сталий розвиток, що передбачає однакову увагу до економічної, соціальної та екологічної складових частин;
- пріоритет функцій біосфери щодо прямого використання її ресурсів;

- запобігання негативним екологічним наслідкам у результаті господарської діяльності, облік віддалених екологічних наслідків;

- відмова від проектів, пов'язаних із впливом на природні системи, якщо їхні наслідки є непередбачуваними для навколишнього середовища;

- природокористування на платній основі та відшкодування шкоди, що завдається в результаті порушення законодавства.

Зі зростанням глобальних екологічних проблем зацікавленість в екологічних інноваціях, які можуть бути впроваджені на підприємствах, посилюється. Такі інновації спроможні не лише забезпечити соціальноекологічну відповідальність у бізнесовій сфері, але й надати конкурентні переваги підприємствам. Культура споживання та принципи сталого розвитку формують нові підходи до функціонування промислового сектору економіки, коригуючи технології та їх технічне забезпечення, розвиваючи свідоме стратегічне бачення топ-менеджменту у сталому розвитку [8]. На підтвердження зазначеному, починаючи 32016 p. кількість впроваджуваних на підприємствах маловідходних, ресурсозберігаючих, технологічних процесів, хоч і незначно, проте зростає (рис. 1). Це свідчить про активізацію процесів усвідомлення необхідності змін під впливом обмеженості ресурсів, підвищення контролю за забрудненнями та оновлення техніко-технологічного забезпечення підприємств технологіями нової формації.

Проте варто зазначити, що за наявності позитивної тенденції впровадження нових екоорієнтованих технологічних процесів на підприємствах їхнє відсоткове значення у структурі технологій є не досить значним (рис. 2). Так, у 2016 р. воно становило не більше $21 \%$, a у 2019 . p. $-37 \%$ [9].

Із плином часу екоінновації перетворюються на бізнес-підходи, що забезпечують стійкий розвиток підприємству, підвищуючи ефективність та конкурентоспроможність. Основними чинниками, що спонукають підприємства до впровадження екологічний інновацій, у цьому аспекті вважаються [10]:

- орієнтація на причинний характер дій, який передбачає подолання під час здійснення інноваційних процесів причин, а не наслідків;

- розмежування відповідальності, яке визначає адресність та ступінь відповідальності суб'єктів екодеструктивної дії;

- формування мотиваційного інструментарію, адекватного наявним соціально-економічним умовам;

- максимізація ефективності, яка передбачає досягнення цілей $з$ екологізації $з$ мінімальними витратами й отриманням максимальної віддачі інвестиційних засобів.

Екологічний контекст розвитку підприємства 3 позиції керівництва та партнерів підприємства набуває все більшого значення й одержує фінансову результативність і підтримку, формуючись у систему екологічного менеджменту підприємства. Аналізуючи капітальні інвестиції на охорону навколишнього природного середовища за видами економічної діяльності підприємств у 2019 р., можна зазначити, що в основному такі витрати спрямовувалися на заходи 


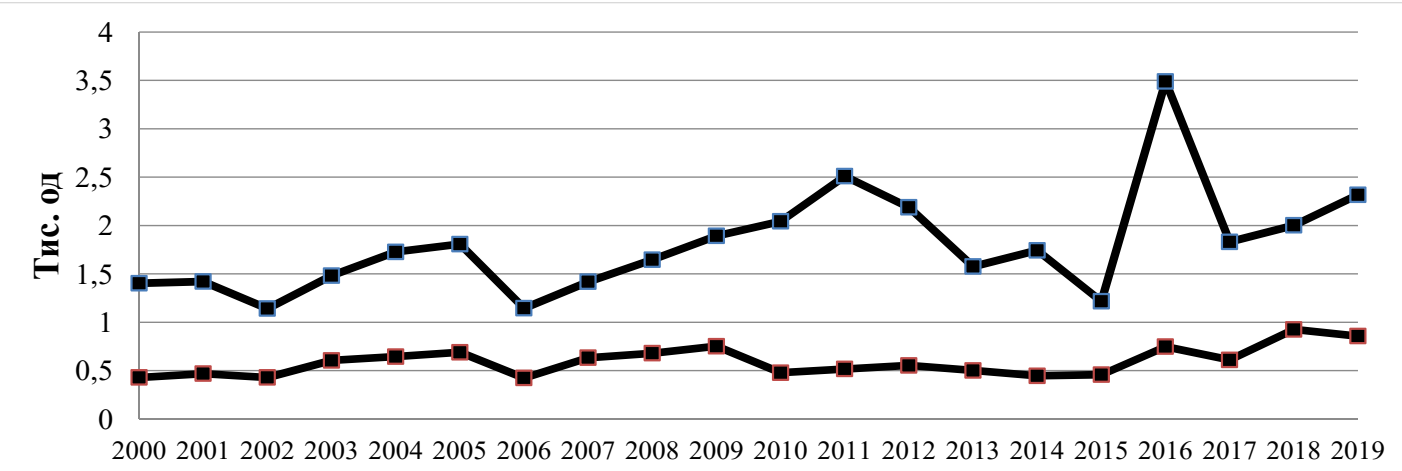

-ш-Кількість упроваджених у виробництво нових технологічних процесів, тис. од.

- -3 них нових або суттєво поліпшених маловідходних, ресурсозберігаючих технологічних процесів, тис. од

Рисунок 1 - Кількість упроваджуваних нових технологічних процесів на підприємствах України, тис. од.

Джерело: складено за даними [9]

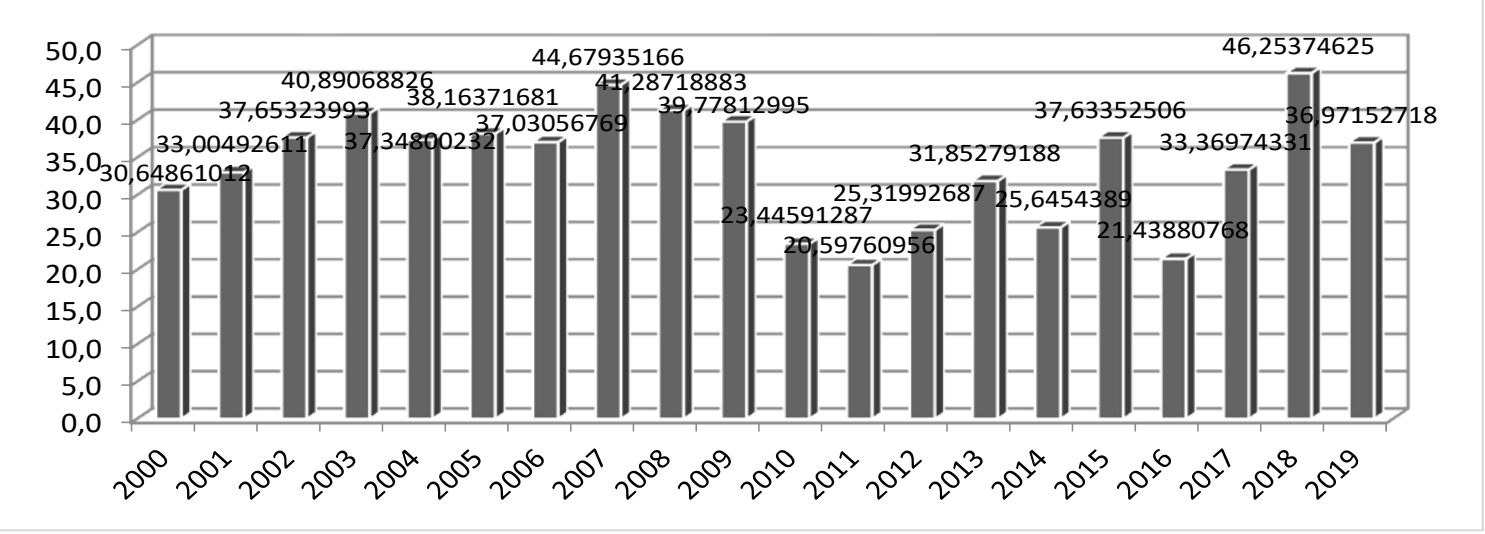

Рисунок 2 - Частка нових або суттєво поліпшених маловідходних, ресурсозберігаючих технологічних процесів, впроваджених на підприсмствах України, \%

Джерело: розраховано за даними [9]

3 охорони атмосферного повітря і проблеми зміни клімату, а також очищення зворотних вод. Проте на поводження з відходами витрачалося значно менше (рис. 3a). Серед активних у цьому напрямі були підприємства, що виробляють харчові продукти, кокс та продукти нафтоперероблення, хімічних речовин і хімічної продукції. У блоці підприємств металургійного виробництва та машинобудування (рис. 3б) спостерігається висока активність за першим видом діяльності. Це насамперед пов'язано з його специфікою. Однак у машинобудуванні стан фінансування охорони навколишнього середовища є дещо низьким, зважаючи на екологонебезпечність його процесів виробництва.

Отже, для забезпечення стійкого розвитку, безумовно, важливого значення набуває впровадження екологічних інновацій на вітчизняних промислових підприємствах. Впровадження екологічних інновацій $\epsilon$ капіталомістким процесом. Тому вони повинні мати виважену економічно-екологічну політику. Доречно звертати увагу на законодавчі обмеження, вимоги національних i міжнародних стандартів, ефективність витрат на екологізацію виробництв. Доцільним заходом у цьому контексті є сертифікування за міжнародним стандартом ISO 14001 або EMAS, а також комплекс запроваджень 3 екологічного маркетингу, екотехнологій. Серед екологічних інновацій, які пропонують науковці для впровадження на підприємствах, є: розроблення, створення і впровадження нових технологічних процесів і циклів розроблення й погодженого розвитку всіх функціональних ланок із видобування ресурсів, їх перероблення, використання відходів і відтворення цих ресурсів; розроблення і використання ресурсозберігаючої техніки, розроблення і впровадження маловідходних і безвідходних технологій, що забезпечують комплексне освоєння природних ресурсів, розроблення біотехнології; освоєння нових територій, а також розширення тих, що діють, з урахуванням екологічної безпеки населення i виробництва; розроблення і випуск нових еколо- 


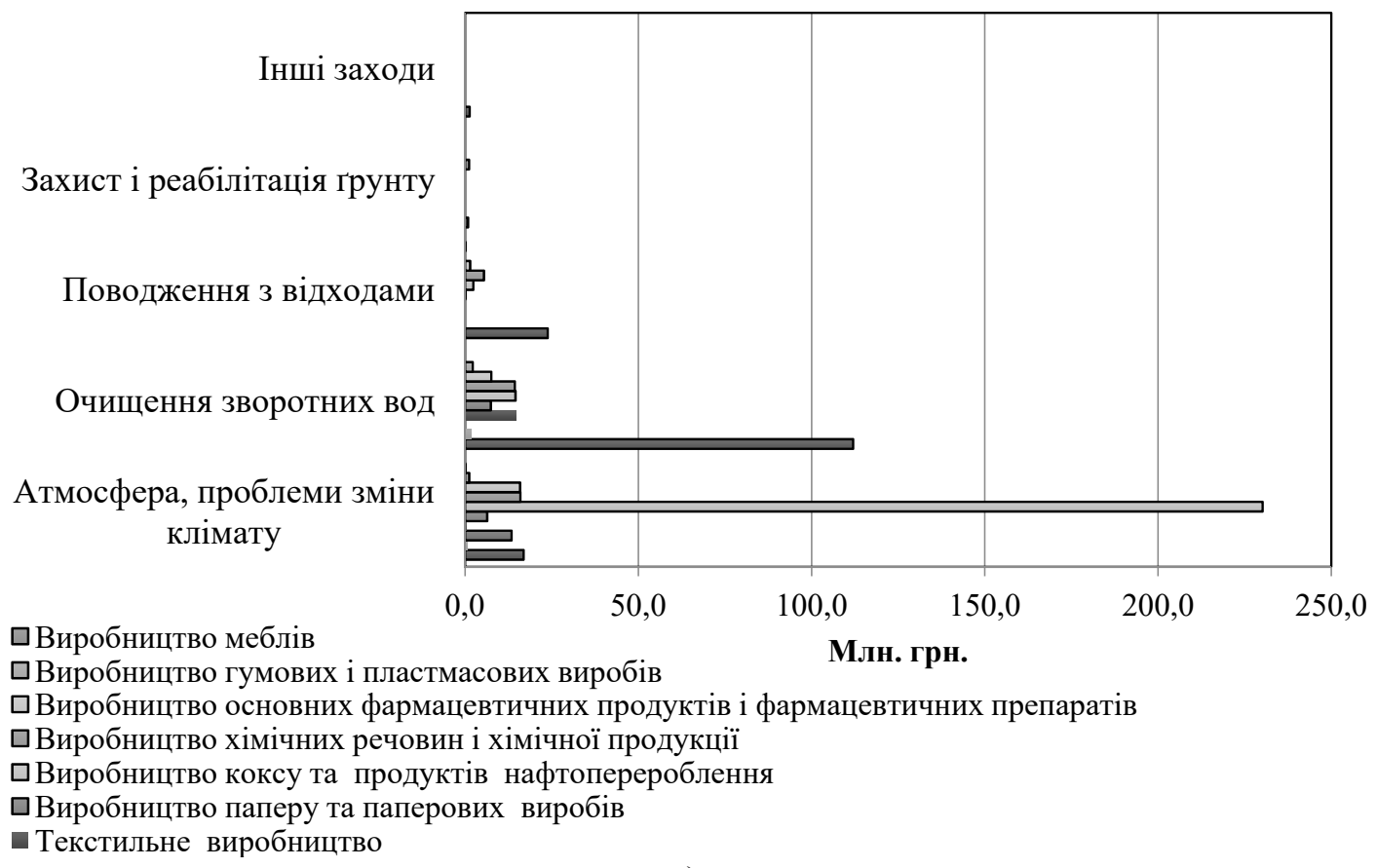

a)

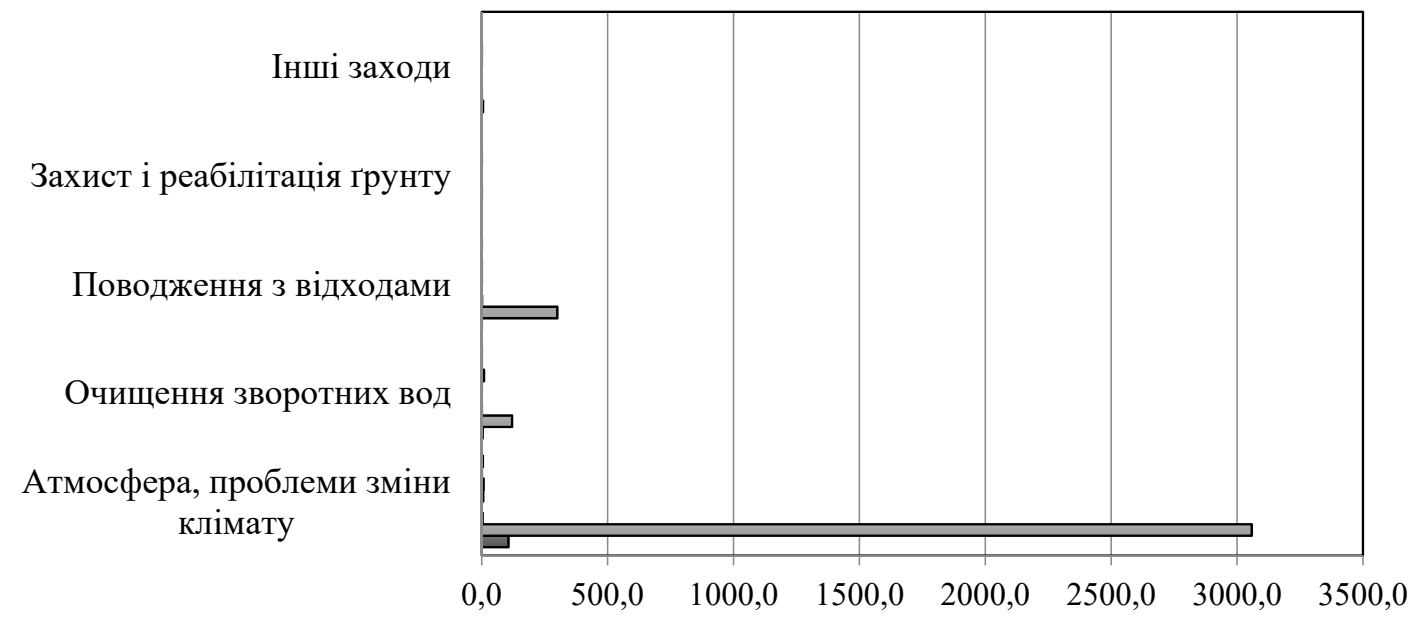

口Виробництво інших транспортних засобів

Млн. грн.

口Виробництво автотранспортних засобів, причепів і напівпричепів

口Виробництво машин і устатковання, н.в.і.у.

口Виробництво електричного устатковання

ш Виробництво комп'ютерів, електронної та оптичної продукції

$\square$ Виробництво готових металевих виробів, крім машин і устатковання

口Металургійне виробництво

口Виробництво іншої неметалевої мінеральної продукції

б)

Рисунок 3 - Обсяги капітальних інвестицій за видами економічної діяльності підприємств України, млн. грн.

Джерело: складено за даними [9]

гічно чистих продуктів і створення потужностей для їх виробництва, розроблення варіантів використання нових і поновлюваних джерел енергії; впровадження нових організаційних форм, включаючи удосконалення організаційно-територіальної структури потенційно небезпечних виробництв із метою зниження екологічної небезпеки; формування нового мислення у розробників інновацій з погляду необхідності їх екологізації шляхом впровадження обов'язкової екологічної освіти [11].

Водночас на шляху до впровадження екологічних інновацій на підприємствах є низка проблем. Зокрема, недостатність стимуляційних заходів щодо інноваційної екологізації виробництв, нерозвинений ринок 
екологічних інновацій в Україні, відсутність достатніх фінансових ресурсів для зміни техніко-технологічних процесів. Тому для активізації процесів екологізації має бути сформовано та забезпечено низку економічних умов:

- розвиток страхового ринку в контексті страхування діяльності підприємств у разі втрат від розроблення та впровадження екоінновацій;

- розвиток ринку нетрадиційних джерел енергії, субсидіювання промислових підприємств для переходу на їх використання;

- створення кластерів екологічно орієнтованого виробництва, які би включали виробників екологічної сировини, кінцевої продукції, енерго-, ресурсозберігаючих, екологічно-безпечних технологій;

- підвищення інвестиційної привабливості вкладення ресурсів в економізацію виробництв;

- формування фондів спеціального призначення на підприємствах, які розробляють та впроваджують екологічні інновації;
- формування програми розвитку екоінновацій у промисловості.

Зазначені пропозиції забезпечуватимуть сталий розвиток підприємств, вирішать питання стимулювання впровадження екологічних інновацій на підприємствах, створять умови доступності інвестиційного ресурсу для екоінновацій, підвищать економічний інтерес підприємств до їх впровадження.

Висновки. Екологічні інновації $\epsilon$ інструментом вирішення не тільки екологічних, але й економічних проблем вітчизняних промислових підприємств. Вибір вектором розвитку екологічності дасть їм змогу насамперд забезпечити спроможність сталого розвитку, підвищити конкурентоспроможність не тільки на вітчизняному ринку, а й на ринках інших країн. Упровадження екоінновацій дасть змогу знизити рівень екологонебезпечності підприємств промисловості України, як високотехнологічної сфери, так і нижчих технологічних укладів, надаючи потенційні можливості підвищувати показники економічної діяльності.

\section{Список використаних джерел:}

1. Rennings K., Zwick, T. (Eds) Employment Impacts of Cleaner Production, ZEW Economic Studies 21, Physica Verlag Heidelberg, New York. 2003. URL: https://www.springer.com/gp/book/9783790800937 (дата звернення: 10.09.2020).

2. Chodyński A. Wiedza i kompetencje ekologiczne w strategiach rozwoju przedsiębiorstw. Difin Warszawa, 2007. 213 p.

3. Горбач Л.М. Екологічні інновації як визначальний елемент нової моделі природокористування. Економіка природокористування і охорони довкілля. 2013. № 4. С. 89-94.

4. Савчук О.Я. Яворська Н.П. Концептуальні підходи до уточнення поняття «еко-інновації». Науковий вісник НЛТУ. 2012. Вип. 22.4. С. 106-113.

5. Скороход I.С., Ребрина Н.Г. Дослідження факторів еко-інноваційної діяльності підприємств в умовах транскордонного співробітництва. Соціально-економічні проблеми сучасного періоду України, 2015. Вип. 1 (111). С. 127-131.

6. Приходько І.В. Підходи до трактування сутності поняття «еко-інновації». Международный научный журнал «Интернаука», 2018. № 2 (42). С. 45-49.

7. Екологія і промисловість: Український бізнес за європейськими правилами. ТОВ «Побузький феронікелевий комбінат». 17.11.2017. URL: https://pfk.com.ua/ekologiya-i-promislovist-ukra\%D1\%97nskij-biznes-za-yevropejskimi-pravilami/ (дата звернення: 10.09.2020).

8. Бичковська А. Екологічні інновації промислових підприємств у забезпеченні сталого розвитку. Бізнес, інновації, менеджмент: проблеми та перспективи: зб. тез доп. ІМіжнародної наук.-практ. конф., 23 квіт. 2020 p. URL: http://confmanagement.kpi.ua/ proc/article/view/201180 (дата звернення: 20.08.2020).

9. Державна служба статистики України. 2020. URL: http://www.ukrstat.gov.ua/ (дата звернення: 21.09.2020).

10. Лесняк О., Логвинюк А. Проблеми впровадження екологічних інновацій в Україні. URL: http:// conferences.neasmo.org.ua/ node/486. (дата звернення: 25.09.2020).

11. Андрєєва Н.Н., Мартынюк Е.Н. Экологические инновации и инвестиции: сущность, системология, специфика взаимодействия и управления. Вісник Хмельницького національного університету, 2011. № 2. Т. 2. С. 207.

\section{References:}

1. Rennings K., Zwick T. (Eds.) (2003) Employment Impacts of Cleaner Production, ZEW Economic Studies 21, Physica Verlag Heidelberg, New York. URL: https://www.springer.com/gp/book/9783790800937 (accessed 10 September 2020).

2. Chodyński A. (2007) Wiedza i kompetencje ekologiczne w strategiach rozwoju przedsiębiorstw. Difin Warszawa.

3. Horbach L.M. (2012) Ekolohichni innovatsii iak vyznachal'nyj element novoi modeli pryrodokorystuvannia [Ecological innovations as a defining element of a new model of nature management]. Ekonomika pryrodokorystuvannia $i$ okhorony dovkillia, no. 4, pp. 89-94.

4. Savchuk O.Ya., Yavors'ka N.P. (2012) Kontseptual'ni pidkhody do utochnennia poniattia eko-innovatsii [Conceptual approaches to the precise term "eco-innovation"]. Naukovyj visnyk NLT, vol. 22.4, pp. 106-113.

5. Skorokhod I.S., Rebryna N.H. (2015) Doslidzhennia faktoriv eko-innovatsijnoi diial'nosti pidpryiemstv v umovakh transkordonnoho spivrobitnytstva [Study of factors influencing the eco-innovation activities of companies under cross-border cooperation]. Sotsial'no-ekonomichni problemy suchasnoho periodu Ukrainy, vol. 1 (111), pp. 127-131.

6. Prykhod'ko I.V. (2018) Pidkhody do traktuvannia sutnosti poniattia eko-innovatsii [Approaches to the definition of the «ecoinnovation» concept]. Mezhdunarodnyj nauchnyj zhurnal «Ynternauka», no. 2 (42), pp. 45-49.

7. Ekolohiia i promyslovist': Ukrains'kyj biznes za ievropejs'kymy pravylamy (2017) [Ecology and industry: Ukrainian business according to European rules] "TOV Pobuz'kyj feronikelevyj kombinat". Available at: https://pfk.com.ua/ekologiya-i-promislovistukra\%D1\%97nskij-biznes-za-yevropejskimi-pravilami/ (accessed 20 August 2020).

8. Bychkovska A. (2020) Ekolohichni innovatsii promyslovykh pidpryiemstv u zabezpechenni staloho rozvytku [Ecological innovations of industrial enterprises in ensuring sustainable development]. Biznes, innovatsii, menedzhment: problemy ta perspektyvy: zb. tez dop. I Mizhnarodnoi nauk, [Online]. Available at: http://confmanagement.kpi.ua/proc/article/view/201180 (accessed 20 August 2020).

9. Derzhavna sluzhba statystyky Ukrainy (2020) [State Statistics Service of Ukraine], "News", available at: http://www.ukrstat.gov.ua/ (accessed 21 September 2020). 
10. Lesniak O., Lohvyniuk A. Problemy vprovadzhennia ekolohichnykh innovatsij v Ukraini [Problems of implementation of ecological innovations in Ukraine]. Available at: http://conferences.neasmo.org.ua/node/486 (accessed 25 September 2020).

11. Andrieieva N.N., Martyniuk E.N. (2011) Ekolohycheskye ynnovatsyy y ynvestytsyy: suschnost', systemolohyia, spetsyfyka vzaymodejstvyia y upravlenyia [Ecological innovations and investments: essence, systemology, specifics of interaction and management] Visnyk Khmel'nyts'koho natsional'noho universytetu, no. 2, vol. 2. p. 207.

\section{Boiarynova Kateryna, Bychkovska Anna} National Technical University of Ukraine «Igor Sikorsky Kyiv Polytechnic Institute»

\section{PROBLEMS AND OUTLOOK OF IMPLEMENTATION OF ECOLOGICAL INNOVATIONS AT ENTERPRISES}

The study is determined by the need to ensure sustainable development of enterprises, increase their competitiveness and social responsibility for environmental protection. It is dedicated to the analysis of the current situation, progressing problems and prospects of implementation of environmental innovations at enterprises. Based on the use of the monographic method, abstract-logical method, logical generalizations, formalization and concretization were revealed the problems, tendencies and features of implementation of ecological innovations at domestic industrial enterprises. The significance of eco-innovations and its key objects are considered. This article justifies the division of eco-innovations to innovations in the production activities of the enterprise (innovations in the field of emission reduction, water pollution); innovations in the composition of products (creation of products from ecological materials, reusable materials); in the management sphere (energy management, waste management, etc.). The tendencies of implementation of low-waste, resource-saving, technological processes at the enterprises are analyzed in this study. Positive dynamics in terms of quantity was revealed, however, there is the lack of implementation in the structure of such technologies in the implemented new technological processes. The capacity of capital investments in ecological innovations by types of economic activity of Ukrainian enterprises are studied. A low level of activity on financing waste management, soil protection and rehabilitation has been identified. In order to develop ecological processes, it is proposed to provide a number of economic terms: the development of the insurance market, in the context of insurance of enterprises in the field of eco-innovation; subsidizing industrial enterprises for the transition to use of non-traditional energy sources; creation of clusters of ecologically oriented production; increasing the investment attractiveness of resource investment in the ecological production; creation of special purpose funds at enterprises; formation of the program of development of eco-innovations in the industry.

Key words: ecological innovations, eco-innovations, enterprise, technologies, ecological production.

JEL classification: M11, M21, O10, Q5 